\title{
Peredam Konflik Agama: Studi Analisis Penyelesaian di Tolikara Papua 2015
}

\section{MOH ROSYID}

Mrosyid72@yahoo.co.id

\begin{abstract}
This paper aims at understanding the importance of early warning system on interreligious conflict, so that similar case such as the fire incident of Al-Muttaqin Mosque in Karubaga, Tolikara, Papua on Friday Syawal 1st $1436 \mathrm{H} / \mathrm{July} 17^{\text {th }} 2015$. Fire occurred when Muslim performing led Fitri prayer in an open space. The case seemed to be a climax of previous events: 1) Gereja Injili di Indonesia (GIDI/ Indonesian Evangelical Church) held an international seminar involving people from all over the world, on the day of Ied Fitri. Moreover, GIDI released a notice banning Muslim from performing Ied Prayer, 2) the committee of KKR somehow felt irritated with Muslims' activity during led celebration since early in the morning, 3) state apparatus were not prepared for the conflict. Early warning system needs to be developed to prevent such conflict re-occur in this country. The cause of conflict should be settled such as based on the finding of the Fact Finding Team of the Muslims Committee for Tolikara (Komat): the criminals should be brought to the court; the notice released by GIDI should be evaluated; Interreligious forum (FKUB) should be balanced between all religious beliefs; local regulation on the banning of building a place of worship other than GIDI's church must be evaluated.
\end{abstract}

Keywords: harmony, tolerance, consistency

\section{ABSTRAK}

Mudahnya tersulut konflik antar-umat beragama sebagai penanda bahwa toleransi menghadapi dinamika. Hal ini sebagaimana terjadinya kerusuhan yang berakibat terbakarnya kios yang terbuat dari papan dan merembet pada Masjid Al-Muttaqin di Distrik Karubaga, Kabupaten Tolikara, Papua Jumat 1 Syawal 1436 H/17 Juli 2015. Kala itu umat Islam melaksanakan salat Idul Fitri merupakan tindakan intoleran dan kriminal. Pemicu terjadinya kerusuhan akibat (1) seminar Kebaktian Kebangkitan Ruhani (KKR) oleh Gereja Injili di Indonesia (GIDI) Papua yang mengundang ribuan tamu termasuk dari mancanegara bersamaan 
pada Hari Raya Idul Fitri. GIDI membuat surat edaran yang memuat pelarangan salat Id, (2) penyelenggara KKR merasa terganggu karena muslim yang beribadah di ruang terbuka menggunakan pengeras suara sejak subuh hingga pagi, (3) aparat keamanan dianggap tidak sigap dalam mengantisipasi bila terjadi konflik. Upaya yang harus diwujudkan agar hal serupa tidak terjadi lagi di negeri ini adalah melakukan deteksi dini bila embrio adanya konflik dengan melibatkan semua unsur masyarakat bersama pemerintah. Tindakan preventif harus diawali dengan menyelesaikan pemicu konflik di Tolikara yakni temuan Tim Pencari Fakta Komite Umat (Islam) untuk Tolikara (Komat); pelaku berikut ini harus ditindak yakni tindak kriminal (selain yang divonis hakim), pihak yang menerbitkan surat edaran (kontroversial); peran FKUB perlu dievaluasi agar menjadi balance; perda pelarangan pembangunan tempat ibadah bagi non-Kristen dan diperbolehkan hanya Kristen yang tergabung dalam GIDI perlu dievaluasi.

Kata Kunci: harmoni, toleransi, dan konsistensi.

\section{PENDAHULUAN}

Pemerintah Jokowi-JK memiliki perhatian ekstra pada warga Papua. Upayanya dengan mencoba mengondisikan Papua dalam aspek biaya kebutuhan hidup bila dibanding dengan wilayah lain di Indonesia menarik ditelaah. Hingga pertengahan tahun 2015, kebutuhan hidup di Tolikara Papua sangat tinggi bila dibandingkan di Jawa. Harga bensin dan solar Rp 25.000 per liter, di Jawa hanya Rp 8.000 dengan pedagang eceran. Nyala lampu menggunakan jenset pada pukul 18.00 WIT hingga pukul 05.00 WIT, setelah itu listrik dipadamkan. Harga di Tolikara dibandingkan dengan di Kudus, minyak tanah per liter Rp 25.000, gula pasir per kg Rp 30.000 (di Jawa Rp 8.000), beras standar Bulog Rp 20.000 per kg (di Jawa Rp 10.000), sebungkus mie instan Rp 4.000 (di Jawa 1.000). Menu makan dengan ayam goreng Rp 50.000 per porsi (di Jawa per porsi Rp 10.000), bakso Rp 25.000 per mangkok (di Jawa Rp 8.000), teh manis $R p$ 15.000 per gelas di Jawa Rp 1000. ${ }^{1}$ Akan tetapi, setelah Presiden Jokowi dilantik sebagai Presiden RI ke-7 periode 2014-2019 pada 20 Oktober 2014 terdapat hal yang menarik. Kunjungan perdana 27-29 Desember 2014, kedua pada 8-11 Mei 2015, ketiga ke Papua Barat pada 29 Desember 2015 hingga 1 Januari 2016, keempat pada 29-30 April 2016, dan kelima pada 17-18 Oktober 2016.

Pada saat kampanye Capres di Kampung Yoka, sekitar Danau Sentani Papua, 5 Juni 2014 Jokowi menyatakan, istri saya bernama Iriana, asal kata Irian, Papua karena kakek Iriana menjadi guru di Papua bertahuntahun. Berpijak pernyataan ini, Sabtu 27 Desember 2015 Presiden Jokowi 
berkunjung ke Papua pada perayaan Natal 2015 di Stadion Mandala, Jayapura, Papua menyatakan "Saya akan sering hadir di Papua, minimal setahun tiga kali, coba diingat-ingat, kalau kurang ditegur". Presiden mengangkat perempuan Papua yang pertama kali menjadi menteri, yakni Yohana Yembise sebagai Menteri Pemberdayaan Perempuan dan Perlindungan Anak dan Ketua Lembaga Masyarakat Adat Papua, Lenis Kagoya sebagai staf khusus presiden. Banyak kebijakan yang menyejahterakan warga Papua, antara lain one price policy. ${ }^{2}$ Luasnya wilayah Provinsi Papua, di sisi lain prasarana infrastruktur yang belum optimal, Badan Usaha Milik Negara (BUMN) berkiprah membangun dengan program semen murah. ${ }^{3}$

Luasnya wilayah geografis negeri ini memiliki berbagai budaya dan beragam genetika dengan jumlah sekitar 500 etnis. ${ }^{4}$ Etnis tersebut dipilah dalam tiga kelompok populasi (pohon filogenetik). Kelompok pertama merupakan manusia Batak, Jawa, Tengger, Bali, Dayak, Minang, dan Melayu (Riau). Kedua, Sasak, Makassar, Bugis, Sumba Timur, Kaili, Minahasa, dan Sumbawa. Masyarakat suku Toraja di Tana Toraja dan Toraja Utara Sulawesi Selatan diduga kuat merupakan satu rumpun dengan masyarakat di daerah Nias dan Batak. Ketiganya sama-sama penutur Austronesia dengan kesamaan filosofi budaya. Suku Austronesia bermigrasi ke Nusantara pada 4.000 tahun lalu. ${ }^{5}$ Ketiga, manusia Alor dan Papua. Kelompok ketiga ini berbeda dengan kelompok pertama dan kedua karena nenek moyang kelompok ketiga yakni Aborigin Australia. Papua lebih dulu menempati kepulauan Indonesia yakni 50.000-60.000 tahun lalu, disusul kedatangan para migran penutur Austronesia pada 5.000-2.000 tahun Ialu. ${ }^{6}$ Keragaman itu bila tidak dikelola rentan terjadi konflik.

Terjadinya konflik intern dan antar-umat beragama di negeri ini di antaranya diakibatkan oleh pemahaman yang sempit oleh sebagian umat beragama terhadap agamanya dan agama yang dipeluk pihak lain. Terutama perilaku intoleran diperagakan umat mayoritas terhadap umat minoritas di lingkungan mayoritas. ${ }^{7}$ Agama sebagai sistem kepercayaan mempunyai aturan baku yang menjunjung moralitas dan ketaatan atas ajaran Tuhan sehingga agama menjadi institusi kebenaran (the body of truth), hukum (law), dan ritual (rites) yang umatnya harus tunduk pada kekuatan transendental. Dalam realitanya, terjadi pelabelan atas dasar wilayah di Indonesia, seperti Aceh-Islam, Bali-Hindu, dan Kristen-Papua. Hal ini rentan terjadi konflik berupa politisasi sentimen etno-religius di tengah kemajemukan agama (religious plurality) bila disulut faktor pemicu 
konflik (trigger factor). Sebagaimana konflik terjadi di Sambas, Sampit, Ambon, Poso, Maluku Utara, Papua, dsb.

Tahun demi tahun tidak menggembirakan dalam soal kerukunan umat beragama, baik intern maupun antarumat beragama dan umat berkeyakinan di negeri ini. Masalah tersebut berakar pada banyak persoalan, dari dalam dan dari luar agama. Sebagian kelompok memperoleh pemahaman yang sempit tentang agama. Mereka juga kurang mengenal keragaman budaya alias kemajemukan. Faktor luar berasal dari banyak masalah yang membelit masyarakat, seperti kemiskinan, pengangguran, pendidikan, infrastruktur yang lemah atau masalah lingkungan. Pemerintah dinilai oleh masyarakat belum mampu membangun negeri yang sumber daya alamnya melimpah. Penegakan hukum yang lemah, bahkan Korupsi, Kolusi, dan Nepotisme (KKN) kian subur. Tren kekerasan di Indonesia meningkat, toleransi beragama kian terkikis dan radikalisasi agama kian menguat yang terlihat dari merosotnya toleransi terhadap kelompok atau agama lain. Penyebab intoleransi juga akibat tidak ada lagi tokoh masyarakat atau pemimpin yang dihormati. Dulu masyarakat kuat karena ada inisiatif pemimpin lokal, munculnya otoritas tradisional secara turun-temurun karena kharisma pemimpin dalam wujud tokoh adat yang berperan mendamaikan konflik.

Terdapat realitas yang menarik kaitannya dengan respon publik yang resisten (menolak) terhadap Islam radikal. Masyarakat menilai, keberadaan kelompok radikal aktivitasnya mengakibatkan munculnya citra negatif terhadap agama dan umat Islam, bahkan sangat sedikit anggota masyarakat yang bersedia mendukung kelompok radikal. Dialog lintas agama jangan hanya berlangsung di tingkat elit dan bersifat retorika, tetapi dikembangkan hingga menjadi gerakan masyarakat awam dan menciptakan kerukunan dalam kehidupan nyata. Inti penting untuk mengurangi ketegangan atau konflik antarumat beragama. Wacana dialog lintas agama sudah didengungkan oleh pemerintah dan tokoh agama di Indonesia. Namun, selama itu, konflik dan kekerasan atas nama agama masih berlangsung karena dialog itu masih menjadi wacana elit. Data menandaskan bahwa konflik antar dan intern umat beragama menjadi 'tradisi' di negeri ini.

Pada masing-masing kelompok keagamaan tadi, hampir selalu disibukkan oleh dua hal penting. Pertama, bagaimana memantapkan keyakinan atas (aliran) agama yang dipilih. Kedua, bagaimana menjaga 
'solidaritas' satu kelompok (aliran) keagamaan. Karena kondisi ini, sesungguhnya setiap kelompok agama tadi, terdapat kepentingan yang 'tumpang tindih' antara kepentingan agama dengan kepentingan umat beragama. Yang terekspresikan kemudian adalah 'kepentingan umat agama yang mengatasnamakan Tuhan". Di sinilah sejatinya bahwa ketika menyosialisasikan agama berdasarkan pandangan yang sempit maka ia akan membentuk cara pandang umat dengan pandangan yang sempit pula. Dalam pandangan ini, yang muncul ke permukaan adalah klaim kebenaran sepihak. Jika demikian, konflik agama bisa menjadi kesibukan tambahan bagi pemeluk agama yang memperoleh sosialisasi keagamaan seperti itu. Antarpemeluk agama yang kemudian terbentuk dan membentuk in group dan out group sering menghiasi dan dihiasi dengan pandangan prejudice berupa labelling negatif. Dengan demikian, begitu melahirkan 'pengamanan diri bahkan penguatan diri'. Dari sanalah penjelasannya mengapa muncul kecenderungan untuk melihat dan memosisikan kelompok (aliran) keagamaan yang lain adalah ancaman dan mengancam. Prejudice (kecurigaan) seperti itu, oleh masing-masing penganut suatu (aliran) keagamaan secara linier akan 'disahkan' sebagai kebenaran. Fanatisme sempit dalam kehidupan sosial, sebetulnya tidak hanya melulu pada persoalan keimanan tapi sudah tumpang tindih dengan pengarusutamaan pengelompokan yang notabene telah diatributi oleh kesamaan (aliran) keagamaan. Ketika paradigma dalam memandang orang lain yang berbeda sebagai lawan, maka napas yang menghidupi diri adalah kecurigaan sebagai pertanda permusuhan. Efeknya sikap memusuhi sering dimaknai 'jihad agama'. Untuk mengesahkan ungkapan jihad tadi, dengan menempatkan ajaran yang berbeda sebagai hal yang sesat dan menyesatkan. Bagaimana menata ulang keberagamaan yang majemuk? Pertama, kesanggupan untuk memahami bahwa agama yang kami peluk adalah benar menurut kami, sehingga mereka juga punya hak yang sama untuk menyatakan kebenaran menurut mereka. Kedua, jika ada pihak lain mengusik agama kita, sesungguhnya mereka sedang menodai kemuliaan agamanya sendiri. Sama halnya jika kita mengusik keyakinan mereka, sesungguhnya kita juga menodai agama kita sendiri. Keyakinan keagamaan adalah hak individu dalam berurusan kepada Tuhan, sementara memandang mereka sebagai saudara adalah bagian dari ekspresi nurani kita sebagai manusia yang beradab. ${ }^{8}$

Perlu pula memahami empat hipotesa gejala kekerasan berbasis agama 
di Indonesia menurut Rahardjo (1) pengaruh gerakan Islam transnasional seperti Ikhwan al-Muslimin, Hizbut Tahrir, Wahabisme Saudia Arabia, Islam Taliban, dan al-Qaeda. Kesemuanya mencita-citakan tegaknya syariat Islam di semua bidang kehidupan, (2) pengaruh eforia demokratisasi di Indonesia, berpeluang munculnya gerakan Islam radikal yang pada era Orde Baru dibungkam, (3) gagalnya penegakan hukum, dan (4) gagalnya dakwah yang rahmatan lilalamin. ${ }^{9}$

Memandang Indonesia meskipun hanya sekilas perlu diawali memahami karakter warganya. Karakter siapa pun sangat dipengaruhi di mana dan siapa lingkungan yang dijadikan tempat berpijak. Seyogyanya pijakan yang baik, identik dengan pesan pelaku sejarah masa lalu. Jika sejarah leluhurnya baik, maka generasi yang berpijak dari sejarah yang baik tersebut (berpeluang) menjadi baik. Sesuatu yang baik pun dapat 'direkayasa' oleh oknum yang tak bijak menjadi buram, dapat pula karena sentimen kelompok sebagaimana tragedi Jumat 1 Syawal 1436 H/17 Juli 2015 di Karubaga, Kabupaten Tolikara, Papua. Seminar Kebaktian Kebangkitan Rohani (KKR) Gereja Injili di Indonesia (GIDI) pada 15-19 Juli 2015 di Tolikara (daerah pegunungan tengah Papua) yang juga mengundang tamu dari mancanegara bersamaan dengan perayaan Hari Raya Idul Fitri Jumat 17 Juli 2015/1 Syawal 1436 H. Sekelompok pemuda GIDI menyerang umat Islam yang sedang melaksanakan salat Idul Fitri di Karubaga, Kabupaten Tolikara, Papua. Kebaktian Kebangkitan Ruhani (KKR) juga dihadiri Pendeta Benjamin Berger dari Israel dengan lembaganya Kehilat Ha'seh Al-Har Zion (KHAHZ). Bahkan warga setempat diwajibkan mengecat rumah, ruko, trotoar dengan gambar bendera Israel. Bila tidak, didenda Rp 500 ribu. Keberanian pemuda GIDI karena adanya Perda Larangan membangun rumah ibadah baru di Tolikara. Dalihnya sesuai dengan kearifan lokal sebagai daerah otonomi khusus Papua. Perda ini wujud intoleransi kepala daerah dan memicu konflik. Begitu pula adanya surat edaran GIDI yang ditandatangani oleh Ketuanya Nayus Wenda dan Sekretaris Marthen Jingga tertanggal 11 Juli 2015 yang melarang bagi muslim melakukan peribadatan di lapangan terbuka dan menggunakan pengeras suara. Ibadah cukup dilakukan di dalam musala atau ruangan tertutup. ${ }^{10}$

Islam eksis di Papua pada pertengahan abad XV di kepulauan Raja Ampat Sorong yang dibawa oleh Kesultanan Bacan di Maluku Utara melalui kontak perdagangan, budaya, dan politik. Pada abad ke XVI di bawah kesultanan Tidore, Islam terlembaga dan dalam struktur kerajaan di 
Kepulauan Raja Ampat (Kerajaan Waigeo, Batanta, Salawati, dan Misool). Berdiri pula 9 kerajaan atau pertuanan di daerah Fak-fak dan Kaimana, yakni Namatota, Rumbati, dan Patipi. Keberadaan Belanda di Papua abad XIX membuat Islam perkembangannya lambat di tengah gencarnya misionarisasi Kristen. Setelah Papua berintegrasi dengan Indonesia pada tahun 1963, Islam meningkat lagi. Tahun 2006 Islam di Papua mencapai 24 persen dari total penduduk Papua sekitar 2,6 juta jiwa. Era Reformasi dengan otonomi khusus yang identik dengan papuanisasi dan kristenisasi, Islam mulai terpinggirkan. Akan tetapi, dengan kebijakan reformasi yang membuka partisipasi publik mampu meningkatkan posisi dan peran sosial politik muslim di Papua. ${ }^{11}$ Akan tetapi, konflik yang mengejutkan publik terjadi pada 1 Syawal 1436 H/2015 M muslim sebagai umat minoritas diserang umat kristiani sebagai mayoritas tatkala salat Idul Fitri.

\section{PAPUA DALAM PANGKUAN NKRI}

Berdasarkan Survei Sosial Ekonomi Nasional tahun 2009, kemiskinan di Papua (37,5 persen), Papua Barat (35,7 persen), dan Maluku (28,2 persen). Sedangkan gizi buruk di bawah usia 5 tahun, NAD (10,7 persen), Sulbar (10 persen), dan Maluku (9,3 persen). Kematian ibu melahirkan karena tak ditangani medis menjadi penyebabnya. Pertolongan medis karena kelahiran di Papua (49,17 persen), Sulbar (47,57 persen). Tebaran kemiskinan dan minimnya akses pendidikan warga didominasi wilayah Indonesia Timur. Angka partisipasi murni nasional usia 7-12 tahun pada tahun 2008 mencapai 95,14 persen, tahun 2009 mencapai 95,23 persen. Tetapi di Papua dan Sulbar hanya 87 persen. Angka partisipasi murni usia 13-15 tahun pada tahun 2008 mencapai 96,20 persen, tahun 2009 menjadi 98,11 persen. Tetapi di NTT, Papua Barat, dan Papua tercapai 5961 persen. ${ }^{12}$ Adanya kesenjangan tersebut berpeluang tercipta konflik karena mudah dipicu oleh unsur lain.

Memahami hal tersebut, perlunya mengilas balik sejarah kokohnya warga Papua bergabung dengan Negara Kesatuan RI (NKRI). Sebanyak 110 anggota Dewan Musyawarah Penentuan Pendapat Rakyat (Pepera) Irian Barat (kini Papua) di Kabupaten Jayapura pada 4 Agustus 1969 dengan suara bulat menyatakan tetap memilih NKRI. Dengan demikian, berakhirlah Pepera di seluruh Irian Barat. Penentuan pendapat rakyat di bawah pengawasan PBB itu merupakan pelaksanaan dari Kesepakatan New York (New York Agreement) antara Indonesia dengan Belanda di PBB 15 Agustus 
1969. Delapan kabupaten, yakni Merauke, Pegunungan Jayawijaya, Paniai, Fakfak, Sorong, Manokwari, Teluk Cenderawasih, dan Jaya Pura secara aklamasi memilih tetap berada dalam naungan NKRI. Jalan panjang Irian Barat menjadi wilayah NKRI diperlukan waktu 24 tahun sejak Indonesia diproklamirkan 17 Agustus 1945. Belanda ingin menguasai Indonesia melalui Aksi Polisionil I (21 Juli-5 Agustus 1947) dan Aksi Polisionil II (19 Desember 1948-5 Januari 1949). Setelah melalui Perjanjian Linggarjati (1947), Perjanjian Renville (1948), Perjanjian Roem-Royen (1949), dan kecaman PBB atas aksi polisionil Belanda, akhirnya Belanda mengakui kedaulatan Indonesia, tetapi khususnya mengenai Irian Barat disepakati untuk menunda pembahasannya selama satu tahun. Namun, karena Belanda terus menunda pembahasan tentang Irian Barat, akhirnya pada 1954, Perwakilan Tetap Indonesia di PBB memasukkan masalah Irian Barat ke dalam agenda PBB. Tak adanya tanggapan yang memadai dari Belanda maka Presiden Soekarno mencanangkan Operasi Trikora (Tri Komando Rakyat) yang berakhir pada 15 Agustus 1962 saat Indonesia dan Belanda menandatangani Kesepakatan New York. Isinya, Belanda menyerahkan Irian Barat kepada PBB (United Nations Temporary Executive Authority/ UNTEA). Kesepakatan itu menetapkan, sebelum akhir tahun 1969 akan diselenggarakan Pepera. Sidang Majelis PBB 19 November 1969 menyetujui hasil Pepera dan Irian Barat tergabung dalam NKRI.

\section{KRONOLOGI KONFLIK TOLIKARA PAPUA JUMAT 1 SYAWAL/IDUL FITRI 1436 H/2015 M}

Dimensi pemicu konflik berupa aspek ekonomi, politik, ideologi, budaya, budaya dan agama, ${ }^{13}$ dan egoisme. ${ }^{14}$ Konflik berdimensi ekonomi dan politik seringkali terkait dengan siapa mendapat apa, siapa kehilangan apa, dan berapa banyak kehilangannya. Konflik berdimensi ekonomi cenderung bersifat riil. Konflik berdimensi budaya dan ideologi memiliki aspek yang lebih fundamental dan cenderung abstrak. Bentuk aksi para pihak yang terlibat konflik sangat bergantung pada bagaimana mereka melihat sumber, tujuan konflik, dan cara penyelesaian konflik.

Secara teoretis, apa pun jenis konfliknya menurut Suyanto ada dua elemen utama yang sering berkombinasi menjadi sumber hakiki konflik. Pertama, elemen identitas atau potent identity-based factors. Kelompok sosial dimobilisasi dengan membawa identitas komunal kelompok, seperti ras, agama, ideologi, dan kepentingan kelompok. Kedua, elemen persepsi 
terhadap distribusi sumber ekonomi, politik, dan sosial dalam masyarakat. Ketika elemen potent identity-based factors dan elemen persepsi tentang ketidakadilan ekonomi-sosial ini bercampur, potensi konflik menjadi sangat tinggi dan memicu konflik yang mengakar (deep-rooted conflict). Karakteristik konflik horizontal yang berdimensi identitas adalah sifatnya yang persisten dan sering tumpang-tindih dengan isu-isu kesenjangan ekonomi. Konflik yang berbasis SARA ini bercampur dengan konflik distribusi sumber produksi, wilayah, ekonomi, dan lapangan kerja sehingga penanganannya rumit. Dalam konflik (latent) hal yang bersifat ideologi salah satu faktor terpenting bila menyangkut persepsi. Agar konflik tidak berkembang, yang dibutuhkan adalah mekanisme sistem peringatan dini sosial (social early warning system). Prinsip dasarnya adalah pemerintah secara proaktif mendeteksi, memantau, menganalisis, dan menangani setiap benih konflik sedini dan secepat mungkin. Deteksi diutamakan pada titik-titik kelompok strategis di tingkat lokal atau titik persentuhan pemerintah dengan masyarakat lokal. Dalam pengembangan mekanisme peringatan dini, yang perlu diperhatikan adalah (1) menentukan siapa yang pantas menjadi penghubung dan pendeteksi kemungkinan terjadinya keresahan sosial di masyarakat, (2) menentukan dan menawarkan kepada masyarakat bentuk penyaluran keluhan keresahan sosial yang dipercaya masyarakat. ${ }^{15}$

Konflik berlatar belakang agama merupakan salah satu masalah serius di dunia, terutama Indonesia. ${ }^{16}$ Salah satu penyebab ketidaknyamanan sosial dipicu oleh persepsi dan pemahaman umat terhadap ajaran agamanya yang sempit, merasa paling benar dan yang lain salah. Hal itu perlu disikapi dengan format dialog. Format dialog intern atau antaragama dapat dilakukan dengan interaksi yang interaktif antar-tokoh dan umat beragama yang seagama dan beda agama. Harapannya, perbedaan persepsi dapat dipahami bila saling dikomunikasikan dan dipahami dengan bekal hati yang sadar akan perbedaan agar tak terjadi konflik. Menurut Shihab praktik dialog memerlukan komitmen penting yang harus dipegang pelaku dialog yakni (a) toleransi, hal ini sulit tercipta jika tidak tercapai saling pengertian dan saling respek. Pada dasarnya toleransi adalah upaya menahan diri agar potensi konflik dapat ditekan dan (b) pluralisme, hakikatnya adalah interaksi positif dalam lingkungan yang majemuk (ragam) dengan tuntutan tiap pemeluk agama bukan saja mengakui keberadaan dan hak agama lain, tetapi saling terlibat dalam memahami 
perbedaan dan persamaan guna tercapainya kerukunan dalam kebhinekaan. ${ }^{17}$

Konflik agama dari aspek internal dapat berupa penodaan agama, penyiaran agama, dan interpretasi atas teks agama yang keblinger. ${ }^{18}$ Aspek eksternal berupa konflik berbasis rebutan sumber ekonomi, lahan politik, penyelewengan hukum/kebijakan, penyalahgunaan pendidikan agama, dan pemberitaan media massa yang provokatif. Isu pemicu konflik agama karena pembangunan atau penggunaan sarana untuk tempat ibadah, siar kebencian agama (hate speech), penyiaran agama, perilaku aliran nonmainstream, aktivitas yang bertentangan dengan ajaran dasar agama (nya). ${ }^{19}$ Masalah yang muncul dari konflik agama dapat berupa delik penodaan agama, ${ }^{20}$ hubungan agama dengan negara, dan perspektif untuk membaca kehidupan beragama. Hal tersebut akan terminimalisasi (terkurangi) bila umat beragama memahami bahwa beragama adalah hak yang diyakini dalam batin (internum) dan diekspresikan dalam kehidupan (eksternum) oleh pemeluk agama sehingga tercipta social order dan social harmony. Peran negara dalam bingkai HAM berupa melindungi (to protect), menghormati, dan memenuhi hak.

Adanya dalih bahwa warisan penjajahan yang mendarah daging menjadi fondasi hidup sehingga di antara kita tidak toleran. Dalih tersebut tidak berdasar karena penjajahan telah lama berlalu dan pembangunan manusia seutuhnyalah yang belum utuh menjadi penyebabnya. Terjadinya konflik boleh jadi dipicu oleh pemaknaan 'kebebasan'. Adanya ungkapan "tidak ada kebebasan tanpa batas' atau kebebasan seseorang dibatasi oleh kebebasan orang lain. Ungkapan itu benar secara normatif, tetapi problematis di tingkat praktis-aplikatif. Persoalannya, domain kebebasan dan batas-batasnya tidak memiliki ukuran dan standar yang baku, jelas, dan terukur. Kenyataannya, ukuran kebebasan sering dibuat sendiri oleh individu atau kelompok yang memiliki kuasa atau dekat dengan sumber kuasa. Ukuran batasan kebebasan semacam ini pada kenyataannya sering disalahgunakan oleh individu atau kelompok untuk melakukan glorifikasi diri di satu sisi dan demonisasi yang lain di sisi lain. Sikap ini tak jarang berujung pada pengerdilan dan pembatasan hak sipil warga (civil rights). Mengapa negara berperilaku paradoks dalam konteks kehidupan beragama karena kehidupan beragama tersandera politik-kekuasaan. Era demokrasi prosedural-elektoral memungkinkan terjadinya pertukaran kepentingan dengan dukungan politik. ${ }^{21}$ 
Tolikara dengan luas wilayah 6.129,66 km pada tahun 2013 dihuni 125.326 orang. Hasil pemekaran wilayah dari Kabupaten Jayawijaya tahun 2002. Kerusuhan di Tolikara pada 1 Syawal meludeskan 63 kios yang terbuat dari papan kayu dan merembet terbakarnya Masjid Al-Muttaqin (Masjid telah bersertifikat, bukan tanah ulayat) di Karuba, Kabupaten Tolikara, Provinsi Papua pada 17 Juli 2015/1 Syawal 1436 H. Kebakaran tatkala umat Islam melaksanakan salat Idul Fitri di lapangan terbuka karena banyaknya jamaah, sehingga jamaah salat bubar di tengah pelaksanaan salat. Dalam liputan Majalah Mingguan Tempo edisi 27 Juli s.d 2 Agustus 2015, tragedi ini menjadi headline dengan kronologi sebagai berikut:

\begin{tabular}{ll}
\hline $\begin{array}{l}\text { PUKUL } \\
\text { (WAKTU INDONESIA } \\
\text { TIMUR) }\end{array}$ & KEJADIAN \\
\hline 07.05 & $\begin{array}{l}\text { Pada rakaat pertama takbir kelima salat Idul Fitri, para pemuda GIDI } \\
\text { menghentikan salat karena di ruang terbuka (lapangan Koramil); }\end{array}$ \\
\hline 07.15 & Massa yang datang makin banyak; \\
\hline 07.20 & $\begin{array}{l}\text { Tembakan peringatan dari lapangan Koramil. Pemuda melempar batu } \\
\text { ke arah lapangan. Kapolres menenangkan massa. Jamaah salat } \\
\text { berlindung di Kantor Koramil; }\end{array}$ \\
\hline 07.30 & $\begin{array}{l}\text { Api dari kios nomor 6 milik Ali Mukhtar, tokoh muslim Tolikara } \\
\text { merembet membakar masjid yang di belakangnya; }\end{array}$ \\
\hline 08.00 & $\begin{array}{l}\text { Api melalap semua kios; } \\
08.30\end{array}$ \\
\hline 09.00 & $\begin{array}{l}\text { Polisi yang berada di Bank Daerah Papua (BDP), Koramil, antara kios } \\
\text { dan lapangan membubarkan massa; }\end{array}$ \\
\hline
\end{tabular}

Kejadian yang baru pertama kali itu mengakibatkan korban tewas Endi Wanimbo berusia 15 tahun karena tembakan peringatan. Tembakan memicu marahnya 54 orang pendemo yang kemudian membakar kios dan merembet pada masjid. Korban tewas ditemukan di dekat kios yang menghadap ke kantor Bank Daerah Papua. Ada pula 11 warga Tolikara lainnya mengalami luka tembak, 6 dibawa ke rumah sakit umum daerah Jayapura dan yang 5 dibawa ke rumah sakit Wamena. Ada 58 kios terbakar, 24 bangunan rusak, dan 16 bangunan dijarah isinya, 153 jiwa dari 38 KK menjadi korban. Informasi sebelumnya bahwa pelaksanaan salat Id di Karubaga dijamin aman oleh Kapolres Tolikara AKBP Soeroso dan Presiden 
GIDI (Gereja Injili di Indonesia) Dorman Wandikmbo. Tetapi, enam hari sebelum kejadian (sebelum 1 Syawal), GIDI wilayah Tolikara mengeluarkan surat edaran yang berisi larangan bagi muslim salat Idul Fitri di Karubaga dan semua umat gereja non-GIDI pun dilarang melaksanakan kegiatan karena ada seminar KKR mengundang 2.500 tamu, termasuk perwakilan dari Belanda, Amerika Serikat, Papua Nugini, Palau (kepulauan kecil di lautan pasifik), dan Israel. Tujuan surat edaran agar seminar GIDI berskala internasional pada 13-19 Juli 2015 berjalan khusuk. Pembuatan surat edaran dirapatkan tiga kali dan diberikan pada Bupati Tolikara Usman G.Wanimbo dan Kapolres. Akan tetapi, tembusan surat edaran tidak diterima Kapolres. Surat edaran diperoleh Kapolres melalui staf intel Polres yang diperoleh dari pos Komando Pasukan Khusus dan diberikan pada Kapolres pada 13 Juli 2015 pukul 10 pagi. Pada hari yang sama, Imam Masjid Al-Muttaqin Tolikara menghadap pada Kapolres perihal surat edaran. Kapolres langsung menelepon Presiden GIDI Dorman Wandikmbo, Dorman menyatakan akan mencabut surat edaran. Hari berikutnya, Kapolres menelepon Bupati Tolikara yang sedang di Jakarta (berangkat Minggu pagi ke Jakarta lima hari sebelum kerusuhan) perihal surat edaran. Bupati menelepon Badan Pengurus GIDI Wilayah Tolikara Pendeta Nayus Wenda, kemudian ada upaya surat edaran akan diralat. Hal itu diinformasikan Bupati pada Kapolres via telepon. Dalam ralat surat ditandatangani 15 Juli 2015 (dua hari sebelum tragedi) oleh Nayus dan Marthen yang membolehkan salat Id di Distrik Karubaga tapi hanya di masjid dan halamannya, tidak di lapangan terbuka (salat di lapangan terbuka karena masjid tidak muat). Ada pula larangan memakai jilbab dan larangan bagi denominasi lain (selain GIDI) membangun tempat ibadah di Tolikara, termasuk larangan bagi Gereja Advent di Distrik Paido karena sudah ditutup dan jemaatnya bergabung dengan GIDI. Surat bernomor 90/SP/GIDI-WT/ VII/2015 (nomor yang sama antara surat awal dengan surat yang diralat) ditujukan pada umat Islam di Tolikara dan ditembuskan pada Bupati Tolikara dan Kapolres Tolikara. Akan tetapi, Kapolres Tolikara dan Imam Masjid Al-Muttaqin Tolikara menerima surat ralat pada 18 Juli 2015 (sehari setelah tragedi). Dalih Nayus dan Marthen memberi surat pada Sabtu 18 Juli karena Bupati Tolikara Usman telah memberi tahu isi surat ralat pada Kapolres via telepon. Presiden GIDI Pendeta Dorman Wandikmbo menyatakan, surat dikeluarkan oleh Ketua Klasis dan Ketua Wilayah GIDI Tolikara melarang salat Id di lapangan terbuka karena bersamaan digelarnya 
ibadah/seminar Internasional GIDI di Kabupaten Tolikara. Kapolres Tolikara, AKBP Soeroso berkoordinasi dengan Presiden GIDI, Bupati Tolikara Usman Wanimbo, sarannya agar salat Id tidak di lapangan terbuka. Menurut Kapolda Papua Irjen Yotje Mende, kerusuhan bukan karena surat edaran 11 Juli 2015 oleh Badan Pekerja Tolikara tapi disalahtafsiri peserta seminar.

Pada fakta lain, menurut Ronny Mandang umat Islam dan Kristen sepakat dengan menyembelih dua ekor sapi (satu dari muslim dan yang satunya dari Kristen) bahwa salat Idul Fitri dilaksanakan asalkan tidak menggunakan pengeras suara dan berlangsung tidak lebih dari pukul 8 pagi. Akan tetapi, pengeras suara sejak pukul 4 subuh sehingga Marthen meminta pengeras suara dimatikan tapi tidak ada respon dari muslim sehingga pemuda gereja (menurut Bupati Tolikara berjumlah 150 orang, dari 2.000 peserta seminar) mulai melempari batu ke arah lapangan yang digunakan salat Id. Saat kejadian, Bupati Usman sedang tidur di ruang kerja karena baru tidur jam 3 pagi. Hal yang menarik untuk ditelaah, menurut Bupati Tolikara, Perda pelarangan pendirian tempat ibadah selain GIDI pernah disahkan oleh DPRD, Gubernur menyetujui dan disarankan untuk berkonsultasi pada Mendagri agar berlaku definitif. Setelah itu dikembalikan ke daerah jika sudah disahkan di Jakarta, kemudian bupati mengeluarkan peraturan bupati tentang perda dalam bentuk keputusan bupati. Tapi prosesnya belum berlanjut. Pelarangan pendirian tempat ibadah selain GIDI menurut Bupati Tolikara agar sejarah lahirnya GIDI tidak dikotori dan sebagai ciri khas Tolikara, sebagaimana Aceh ciri khas Islam. ${ }^{22}$

Data Republika online, Juli 2015 Tim Pencari Fakta (TPF) Komat menyatakan anggota intel Polres Tolikara Bripka Kasrim di Pos Maleo pada Senin 13 Juli 2015 mendapatkan selembar surat dari GIDI Badan Pekerja Wilayah Toli. Surat Nomor 90/SP/GIDI-WT/VII/2015 ditandatangani Ketua Wilayah Toli Pdt Naylus Wenda dan Sekretaris Pdt Marthen Jingga dengan tembusan Polres Tolikara. Surat yang ditujukan kepada umat Islam seKabupaten Tolikara memberitahukan adanya kegiatan seminar dan Kebaktian Kebangkitan Ruhani (KKR) Pemuda Gereja Injili di Indonesia (GIDI) tingkat internasional pada 13 s.d 19 Juli 2015. Poin-poin larangan dalam surat yakni (1) lebaran 17 Juli 2015 tidak diizinkan di wilayah Kabupaten Tolikara, (2) diperbolehkan di wilayah Wamena atau Jayapura, dan (3) muslimah dilarang memakai jilbab. Bripka Kasrim memfoto kopi surat 
Nomor 90 tersebut dan melaporkan melalui handy talky (HT) kepada Kapolres Tolikara, AKBP Soeroso. Surat dikirimkan pada Kapolres. Selanjutnya, Kapolres menelepon Bupati Tolikara Usman Wanimbo, tapi Bupati sedang berada di Jakarta dan kembali ke Tolikara keesokannya harinya (14 Juli 2015). Kapolres membacakan surat Nomor 90, tapi Bupati menjawab tidak benar. Bupati berjanji menginstruksikan pada Ketua GIDI wilayah Tolikara meminta surat Nomor 90 dicabut atau diralat. Kapolres menyetujui upaya sang bupati. Kapolres pun menelepon Presiden GIDI Pdt Dorman Wandikbo yang berada di Jayapura. Dorman menyatakan akan berkoordinasi dengan anggotanya dan akan mengamankan seluruh kegiatan GIDI maupun Lebaran.

Informasi dari Kapolres Tolikara, seminar dan KKR Pemuda GIDI sudah lama direncanakan menghadirkan tamu mancanegara, tapi hingga sebulan, Polres Tolikara belum mendapatkan permohonan izin keramaian dari panitia seminar. Izin harus dari Intelkam Mabes Polri yang diteruskan pada kepolisian terkait. Pada 6 Juli 2015 Kapolres Tolikara memanggil wakil ketua pelaksana Yakob Jikwa yang menanyakan perihal soal izin keramaian dan meminta visa orang asing dan KTP panitia penyelenggara.Yakob menjawab bahwa izin ditangani panitia tingkat provinsi. Kapolres mengecek ke Dir Intelkam Polda Papua, mendapat jawaban belum ada surat izin yang diajukan panitia. Pada 13 Juli 2015 Kapolres memerintahkan Wakapolres dan Kasat Binmas mendatangi sekretariat panitia untuk menanyakan izin keramaian dan permintaan pengamanan. Wakapolres melaporkan pada Kapolres bahwa panitia sedang mengonsep surat izin. Padahal, peserta sudah penuh mengikuti kegiatan. Peserta diperkirakan 2000 orang dan ditambah pihak yang menyaksikan mencapai 4.000 orang.

TPF dan Komnas HAM menyepakati bahwa Perda di Tolikara yang disetujui DPRD Tolikara diberlakukan sejak 2013 adalah tindakan intoleran karena melarang umat beragama selain GIDI tidak diperbolehkan membangun rumah ibadah, merayakan hari raya, dan memakai atribut keagamaan di muka umum, seperti jilbab. Bupati berjanji akan mengirim Perda tersebut ke Komnas Ham dan Kemendagri karena sebelumnya tidak mendapat tembusan. TPF gabungan MUI dan Litbang Kemenag RI pada 19 Juli (selama 7 hari) terdiri M.Adlin Sila, Zainuddin Daulay, Shohibul Farozi, dan Sabara berada di lokasi menyatakan, adanya tragedi diduga untuk mengalihkan isu korupsi Bupati Tolikara Rp 635 miliar. KKR dan 
seminar GIDI belum berizin pada Polres Tolikara. Acara itu anggarannya mencapai Rp 6 miliar. Peran adat di Papua harus dikembalikan semula. Masyarakat adat yang ingin hidup berdampingan dan penuh toleransi dengan masuknya GIDI merusak tatanan toleransi. Temuan TPF, pembakaran dimulai dari rumah Ketua DKM, Sarno yang jaraknya 20 m dengan Masjid Baitul Muttaqin (yang bersertifikat resmi).

\section{SITUASI PASCA-KONFLIK}

Tragedi terjadi Jumat 17 Juli 2015/1 Syawal 1436 H, Wapres Jusuf Kalla Minggu 19 Juli 2015 malam, menginstruksikan pada Kapolri mengambil langkah hukum yang tegas untuk segera menyelesaikannya. Insiden karena ada dua acara yang berdekatan pelaksanaannya, yakni salat Id dan pertemuan pemuka gereja. Kabag Humas Pemda Tolikara Derwes menyatakan, 11 warga terkena tembakan, 1 orang tewas yakni Lenis Wanimbo, 10 orang dirawat di rumah sakit Wamena, 154 korban mengungsi. ${ }^{23}$ Selanjutnya pada 19 Juli 2015 seminar ditutup dan empat hari kemudian tokoh agama di Tolikara melakukan perdamaian di halaman Koramil Karubaga. Pada Kamis 23 Juli 2015 Polda Papua menetapkan Arianto Kogoyo dan Jumdi Wanimbo sebagai tersangka menjadi pelaku perusakan, kekerasan, dan penghasutan saat insiden Tolikara. Mereka menghuni Rumah Tahanan Polda Papua di Jayapura. Menurut Kapolda Papua Irjen Yotje Mende, keduanya berperan sebagai provokator yang melempari batu dan menyerang muslim yang sedang salat Idul Fitri.

Respon dari pemerintah, mewakili Presiden Jokowi, Lenis Kogoya sebagai staf khusus presiden, mengadakan jumpa pers di gedung Sekneg Jakarta 18 Juli 2015 siang. Kogoya memohonkan maaf pada muslim di Indonesia atas insiden di Karuba, Tolikara, Papua. Presiden menurut rencana akan ke Karuba pada 29 Juli 2015 untuk memediasi (akhirnya tidak terealisasi). Permohonan maaf juga datang dari Dirjen Bimas Kristen Odhita R Hutabarat. Ia menghubungi Ketua Sinode GIDI dan Persekutuan Gereja dan Lembaga Injili Indonesia (PGLII) untuk menjelaskan kronologi kejadian. Dugaan keterlibatan Bawil Toli DIGI pada 17 Juli 2015 yang membuat surat larangan pada umat Islam bila merayakan Idul Fitri. Hal ini untuk diusut tuntas. Persekutuan Gereja di Indonesia (PGI) mengecam keras tragedi pembakaran Masjid di Karuba.

Presiden Jokowi pada rapat kabinet terbatas di Istana Negara Jakarta Rabu 22 Juli 2015 menginstruksikan pada Kapolri Badrodin Haiti dan 
Panglima TNI Jenderal Gatot Nurmantyo agar kasus Tolikara ditangani secara komprehensif, yakni penindakan hukum terhadap pelaku, rehabilitasi bangunan rusak, dan menjalin dialog dengan tokoh di Papua. Hal ini diawali sejumlah pemuda GIDI berhadapan dengan aparat kepolisian yang menghalau upaya pemuda GIDI menghentikan salat Idul Fitri di Masjid Baitul Muttaqin yang dibangun tahun 1987. Pasca-kerusuhan di Karubaga, Tolikara, seluruh warga bersatu mengusung semangat kumbiwaruwok yakni bergandengan tangan demi perdamaian selamanya di wilayah Lembah Toli. Pada Rabu 22 Juli 2015 umat Kristen dan muslim setempat bersama-sama membersihkan puing-puing kebakaran. Bupati Tolikara, Usman Wanimbo mempertemukan Ketua GIDI Cabang Tolikara Nayus Wenda yang memimpin 274 gereja di Tolikara dengan Ustadz Ali Muchtar untuk mengucapkan janji untuk menjaga perdamaian di Tolikara (Kompas, 23 Juli 2015). Panglima TNI Jenderal Gatot Nurmantyo diberi waktu satu bulan oleh presiden untuk mempercepat penyelesaian renovasi pembangunan 60 kios yang terbakar -dibangun 75 kios- dan masjid yang rusak akibat insiden Tolikara sehingga TNI menambah 100 pasukan. Ketua Forum Kerukunan antar-Umat Beragama (FKUB) di Papua, Lipiyus Biniluk yang juga Ketua Persekutuan Gereja-Gereja dan Lembaga-Lembaga Injili di Indonesia (PGLII) Papua didampingi Tim Komunikasi Publik Presiden, Teten Masduki dan Staf Khusus Presiden untuk Papua, Lenis Kogaya pada Jumat 24 Juli 2015 diterima Presiden Jokowi di Istana Merdeka (Kompas, 25 Juli 2015).

Kesigapan pemerintah menghentikan kerusuhan diwujudkan dengan memeriksa 50 saksi kerusuhan dan menetapkan 2 tersangka YW dan HK menjalani proses hukum di Polda Papua. Mendagri Tjahjo Kumolo dalam pertemuan dengan Pemerintah Provinsi Papua dan Forum Koordinasi Pimpinan Daerah Provinsi Papua di Jayapura Senin 20 Juli 2015 menyatakan, pemerintah menjamin tersedianya anggaran untuk biaya rekonstruksi akibat insiden Tolikara, dengan memanfaatkan dana hibah atau talangan. Pernyataan itu disampaikan tatkala 250 orang masih mengungsi di depan Markas Koramil 1702 11/Karubaga. Pangdam XVII/Cenderawasih Mayjen Fransen G Siahaan menyatakan tidak keberatan bila lapangan Koramil dipakai sementara untuk menampung pengungsi dan dibangunkan musala sementara. Kapolri menegaskan, tugas Polri adalah menghentikan dan melokalisasi kerusuhan, menjamin dan memelihara keamanan, dan melakukan penegakan hukum terhadap pembakar kios dan pembu- 
baran salat Id. Wakapolda Papua Brigjen (Pol) Rudolf Albert Rodja mengatakan, Polri memeriksa 32 saksi dalam insiden Tolikara. Dirjen Politik dan Pemerintahan Umum Kemendagri Soedarmo mengatakan, untuk mencegah terjadinya insiden sebagaimana di Tolikara, pemda harus meningkatkan fungsi deteksi dini dan dibentuk tim terpadu penanganan konflik sosial di tingkat pusat dan daerah agar semakin tajamnya deteksi dini. ${ }^{24}$ Tim Pencari Fakta (TPF) Komite Umat untuk Tolikara (Komat) yang diketuai Ustad Fadlan Garamatan menyimpulkan bahwa tragedi bukan spontanitas tetapi direncanakan. Ada tiga kelompok yang mengepung jamaah yang sedang Salat Id dari tiga titik, ada suara komando untuk menyerang. ${ }^{25}$

TPF dalam konferensi pers pada Jumat 31 Juli 2015 merekomendasikan (1) masyarakat adat, khususnya di Papua, harus dilindungi UU yang berlaku di NKRI. Masuknya GIDI dengan otoritas kepemimpinannya telah merusak tatanan toleransi dan membuat masyarakat adat terusik, (2) mengembalikan peran adat sebagaimana fungsinya di tengah masyarakat dalam menjaga adat istiadat seluruh masyarakat yang ada di Papua, baik masyarakat asli maupun pendatang, (3) negara harus menjamin kemerdekaan tiap penduduk untuk memeluk agamanya masing-masing, (4) keberadaan GIDI dinilai melakukan pelanggaran HAM karena telah membubarkan salat Id. Pihak terkait harus menemukan dan mengadili aktor intelektual yang menandatangani surat edaran larangan pelaksanaan Salat Id. Tokoh Islam Tolikara Ustad Ali Muchtar (Imam Masjid usia 38 tahun menetap di Karuba tahun 2006) menyepakati agar penyelesaian insiden salat Id di Tolikara diselesaikan dengan cara damai, sedangkan staf khusus Presiden Lenis Kayoga (putra daerah Papua) menghendaki penyelesaian secara adat. la meminta kepada Kapolda Papua menghentikan proses hukum yang sedang berjalan. Menyikapi permintaan ini, Brigjen Paulus Waterpaw, pengganti Kapolda yang lama (sewaktu terjadi insiden) Irjen Yotje Mende saat sertijab Kapolda Papua di Rupatama Mabes Polri Jumat 31 Juli 2015 menjelaskan, kami mengambil langkah setelah hadir dulu di Tolikara. Proses hukum yang sudah berjalan tidak serta merta bisa dihentikan. Sebab, tugas polri adalah melakukan proses penegakan hukum. Pelaku insiden harus mempertanggungjawabkan sesuai aturan hukum. Kapolri Badrodin Haiti mengatakan, tidak mungkin dilakukan penghentian proses hukum yang sedang berjalan dan telah melakukan penahanan. Ketua Komat Ustad Bachtiar Nasir mengatakan, massa yang melakukan penyerangan ratusan 
jumlahnya dan orang pedalaman yang tak paham juga dimobilisasi. Aktor intelektual yang menandatangani surat edaran penyebab insiden harus diadili.

Komnas HAM menemukan empat hal dalam tragedi Tolikara, pertama, bentuk intoleransi dengan adanya perda intoleran, surat edaran GIDI, dan pembubaran ibadah salat Id. Kedua, ada 12 orang yang ditembak dan 1 tewas. Ketiga, ketakutan pascainsiden. Keempat, kepemilikan, yakni pembakaran kios, rumah ibadah, dan rumah pribadi. Komnas HAM memberikan tiga rekomendasi kepada pemerintah terkait tragedi Tolikara, pemerintah harus menjamin (1) tidak akan terjadi insiden serupa, yakni penyerangan yang menyebabkan rasa tidak aman, (2) kebebasan penduduk memilih dan mengamalkan ajaran agama, dan (3) menghukum siapa pun inisiator, provokator, dan pelaku lapangan. TPF Komat mendatangi Komnas HAM pada Kamis 6 Agustus 2015 untuk menyampaikan hasil bukti temuan berupa surat edaran, vidio, dan dokumen.

Menurut Azra, peristiwa Tolikara untuk dijadikan renungan mengevaluasi kecenderungan, gejala, dan dinamika kehidupan beragama di Indonesia. Sudah waktunya setiap dan seluruh pejabat dan pemimpin agama tak merasa puas dengan tradisi kedamaian intra dan antaragama selama ini. Dalam konteks evaluasi beragama secara berani dan jujur, upaya 'menyederhanakan' atau 'menurunkan' (play down) kasus intoleransi keagamaan, seperti peristiwa Tolikara menjadi kontraproduktif. Presiden Jokowi menyatakan insiden Tolikara disebabkan kurangnya komunikasi di antara komunitas GIDI dengan muslim lokal. Mendagri Tjahjo Kumolo menyatakan, bukan masalah SARA, melainkan ekspresi ketidakpuasan di antara kelompok masyarakat yang emosional. Kapolri Badrodin Haiti menyatakan, Tolikara merupakan aksi kriminal (daripada konflik keagamaan/religious harted). Pernyataan itu seolah-oleh ingin menyembunyikan masalah ke bawah karpet, tidak meletakkan semua masalah di atas meja. Hal ini sebagai isyarat keengganan mengakui adanya akar-akar masalah lebih fundamental dan akut yang terkait dengan persepsi bahwa masalah itu terkait agama yang sensitif sehingga jika diungkapkan secara terbuka boleh jadi membuat umat beragama berbeda kian divisive (terpecah belah) menuju konflik dan kekerasan. Pemerintah perlu melakukan tindakan represif dan preventif untuk menghentikan aksi intoleransi dari kelompok agama mana pun, yakni dengan resosialisasi serius dan komprehensif faktor pemersatu bangsa yakni UUD 1945, Pancasila, NKRI, dan Bhinneka Tunggal 
Ika. Hal ini sebagai modal terbaik untuk membangun kehidupan. Oleh karena itu, FKUB perlu diberdayakan agar menjalankan fungsinya secara efektif. Pemimpin agama yang memegang hegemoni toleransi, kerukunan, dan kedamaian terus melakukan penguatan inklusivitas, koeksistensi damai, dan harmoni intra dan antar-agama. ${ }^{26}$.

\section{VONIS HAKIM DAN RASA KEADILAN}

Safrudin selaku Majelis Hakim menjatuhkan vonis pidana penjara selama 2 bulan dan 26 hari pada dua terdakwa yakni Ariyanto Kogoya dan Jundi Wanimbo di PN Jayapura Kamis 18 Februari 2016. Keduanya bertindak sebagai provokator yang memicu kerusuhan di Karubaga, Tolikara, 16 Juli 2015 M/1 Syawal 1436 H. Terdakwa terbukti melanggar Pasal 160 juncto Pasal 55 KUHP yakni menghasut 80 orang untuk menyerang 300 warga yang sedang salat Idul Fitri di halaman Koramil Karibaga pukul 07.30 WIT. Ariyanto mengeluarkan kata-kata 'bubarkan dan hentikan' (salat Id) sehingga terjadi pelemparan batu dan membakar 70 kios dan merembet terbakarnya Masjid Baitul Muttaqin. Sedangkan Jundi berteriak 'hentikan tembakan (aparat) dan bubarkan (jamaah Salat Idul Fitri). Kedua terpidana warga Tolikara dari jemaat GIDI bebas (tidak disel) karena vonis yang dijatuhkan sesuai masa tahanan yang telah dijalani. Jaksa Penuntut Umum Glory dan Suherman menuntut 4 bulan penjara. Adapun selaku penasehat hukum terdakwa adalah Gustaf (Kompas.com, 10 Februari 2016). Vonis tersebut tak mencerminkan keadilan karena dampak yang ditimbulkan meresahkan jalinan kerukunan umat beragama. Rentetan tragedi di wilayah lain pasca-Tolikara, pertama, Sabtu 11 Juli 2015 ditemukan kepala babi ditanam di lokasi pembangunan masjid di Bitung, Sulawesi Utara. Hal ini terjadi karena warga tidak setuju pendirian masjid. Kedua, insiden percobaan pembakaran pintu Gereja Kristen Jawa Tlepok, Dusun Tlepok Rt.1/1 Kecamatan Grabag, Kabupaten Purworejo, Jawa Tengah Senin 20 Juli 2015. Kejadian diketahui sekitar pukul 05.30 Wib oleh Pendeta Ibnu Prabowo. Pintu depan sudah terbakar dan ditemukan kertas tertulis: pesan atas tragedi Papua, bakar gereja se-Jawa. Ketiga, Gereja Baptis Indonesia Saman di Dusun Saman, Desa Saman Rt.1 Kecamatan Bangunharjo, Kabupaten Bantul, DIY Senin 20 Juli 2015 pukul 02.45 Wib mendapatkan percobaan pembakaran oleh 4 orang yang membawa 2 sepeda motor. Di depan pintu gereja digantung ban bekas dan tercium bau bensin, meskipun api dapat dipadamkan. 


\section{MENGANTISIPASI KEBERLANJUTAN KONFLIK}

Perjuangan membebaskan masyarakat dari praktik diskriminasi selalu dilakukan oleh seorang atau beberapa aktor utama. Usaha mereka selalu berhasil jika ditunjang oleh infrastruktur sosial yang kuat. Infrastruktur menyumbang 55 persen dan aktor memberi peran 45 persen dari setiap usaha menghapus diskriminasi di satu kawasan atau negara. Praktik diskriminasi terjadi akibat masyarakat tidak mempunyai toleransi terhadap orang yang mempunyai latar belakang berbeda suku, agama, ras, dan antargolongan (SARA). ${ }^{27}$ Untuk mengantisipasi dan mengatasi terjadinya intoleransi perlu dipetakan akar penyelesaian persoalan berupa mendokumentasikan konflik sebagai data kebijakan.

Pertama, Tim Pencari Fakta (TPF) Komite Umat untuk Tolikara (Komat) yang diketuai Ustad Fadlan Garamatan menyimpulkan bahwa tragedi bukan spontanitas tetapi direncanakan. Ada tiga kelompok yang mengepung jamaah yang sedang Salat Id dari tiga titik dan ada suara komando untuk menyerang. Sebelum kerusuhan, ada surat dari GIDI Badan Pekerja Wilayah Toli dengan Surat Nomor 90/SP/GIDI-WT/VII/2015 ditandatangani Ketua Wilayah Toli Pdt Naylus Wenda dan Sekretaris Pdt Marthen Jingga dengan tembusan Polres Tolikara. Surat yang ditujukan kepada umat Islam se-Kabupaten Tolikara memberitahukan adanya kegiatan seminar dan Kebaktian Kebangkitan Ruhani (KKR) Pemuda GIDI tingkat internasional pada 13-19 Juli 2015. Poin-poin larangan dalam surat yakni (1) lebaran Idul Fitri 17 Juli 2015 tidak diizinkan di wilayah Kabupaten Tolikara, (2) lebaran diperbolehkan di wilayah Wamena atau Jayapura, dan (3) muslimah dilarang memakai jilbab.

Kedua, tewasnya Endi Wanimbo berusia 15 tahun karena tembakan. Korban ditemukan di dekat kios yang menghadap ke kantor Bank Daerah Papua. Ada pula 11 warga Tolikara lainnya mengalami luka tembak, 6 dibawa ke rumah sakit umum daerah Jayapura dan yang 5 dibawa ke rumah sakit Wamena. Ada 58 kios terbakar, 24 bangunan rusak, dan 16 bangunan dijarah isinya, 153 jiwa dari 38 KK menjadi korban. Fakta ini tak tersentuh pelakunya sehingga bebas dari hukuman.

Ketiga, GIDI wilayah Tolikara mengeluarkan surat edaran yang berisi larangan bagi muslim salat Idul Fitri di Karubaga dan semua umat gereja non-GIDI dilarang beribadah karena ada seminar KKR. Seminar mengundang 2.500 tamu, termasuk perwakilan dari Belanda, Amerika Serikat, Papua Nugini, Palau (kepulauan kecil di lautan pasifik), dan Israel. Tujuan 
surat edaran agar seminar GIDI berskala internasional pada 13-19 Juli 2015 berjalan khusuk. Surat edaran dirapatkan tiga kali dan diberikan pada Bupati Tolikara Usman G.Wanimbo dan Kapolres.

Keempat, pengeras suara sejak pukul 4 subuh sehingga Marthen meminta pengeras suara dimatikan tapi tidak ada respon dari muslim sehingga pemuda gereja (menurut Bupati Tolikara berjumlah 150 orang, dari 2.000 peserta seminar) mulai melempari batu ke arah lapangan yang digunakan salat Id. Pada 19 Juli 2015 seminar ditutup dan empat hari kemudian tokoh agama di Tolikara melakukan perdamaian di halaman Koramil Karubaga.

Kelima, Perda pelarangan pendirian tempat ibadah selain GIDI pernah disahkan oleh DPRD, meski Gubernur menyetujui dan menyarankan untuk berkonsultasi pada Mendagri agar berlaku definitif. Setelah itu dikembalikan ke daerah jika sudah disahkan di Jakarta, kemudian bupati mengeluarkan peraturan bupati tentang perda dalam bentuk keputusan bupati. Tapi prosesnya belum berlanjut. Pelarangan pendirian tempat ibadah selain GIDI menurut Bupati Tolikara agar sejarah lahirnya GIDI tidak dikotori dan sebagai ciri khas Tolikara, sebagaimana Aceh ciri khas Islam

Keenam, dugaan keterlibatan Bawil Toli GIDI pada 17 Juli 2015 yang membuat surat larangan pada umat Islam bila merayakan Idul Fitri. Hal ini untuk diusut tuntas.

Ketujuh, Presiden Jokowi pada rapat kabinet terbatas di Istana Negara Jakarta Rabu 22 Juli 2015 menginstruksikan pada Kapolri Badrodin Haiti dan Panglima TNI Jenderal Gatot Nurmantyo agar kasus Tolikara ditangani secara komprehensif, yakni penindakan hukum terhadap pelaku, rehabilitasi bangunan rusak, dan menjalin dialog dengan tokoh di Papua sudahkah dilaksanakan seutuhnya?

Kedelapan, Mendagri Tjahjo Kumolo dalam pertemuan dengan Pemerintah Provinsi Papua dan Forum Koordinasi Pimpinan Daerah Provinsi Papua di Jayapura Senin 20 Juli 2015 menyatakan, pemerintah menjamin tersedianya anggaran untuk biaya rekonstruksi akibat insiden Tolikara, dengan memanfaatkan dana hibah atau talangan.

Kesembilan, Dirjen Politik dan Pemerintahan Umum Kemendagri Soedarmo mengatakan, untuk mencegah terjadinya insiden sebagaimana di Tolikara, pemda harus meningkatkan fungsi deteksi dini dan dibentuk tim terpadu penanganan konflik sosial di tingkat pusat dan daerah agar semakin tajamnya deteksi dini. 
Apakah kesembilan persoalan tersebut sudah terselesaikan pada para pihak sudah dimintai pertanggungjawaban? dan bagaimana hasil evaluasinya? Terbatasnya mengakses data pascatragedi 1 Syawal 2015 di Tolikara, penulis berhipotesa bahwa persoalan tersebut lenyap karena tertutup oleh dinamika lain. Media pun tak menganggap lagi sebagai hal aktual dan pemerintah pun disibukkan dengan persoalan lain. Bila demikian, bara berpeluang menjadi api bila terpercik persoalan sekecil apa pun. Jadi, wajarlah bila Ustad Fadzlan Garamatan - ustad asli Papuamembuat surat yang berjudul 'terima kasih GIDI' "Atas ulah kalian, kami jadi tahu nama Tolikara yang sebelumnya sama sekali tak tahu-menahu; bahwa di Tolikara ada masjid yang sudah berdiri puluhan tahun lalu; ada ribuan muslim di Tolikara; ada Perda aneh di Tolikara yang sangat diskriminatif terhadap Islam dan kaum muslimin; Australia dan Israel ternyata sudah menancapkan kuku hitamnya di Bumi Cenderawasih; perkembangan dakwah Islam di Papua secara umum dari hari ke hari terus menggembirakan; jumlah total kaum muslimin di Papua ada 40 persen, populasi yang cukup membalikkan asumsi kebanyakan orang selama ini bahwa Papua hampir identik Kristen atau diklaim Kristen; dari berbagai penjuru tergerak rasa solidaritasnya; Kami yakin masjid yang dibakar akan dibangun kembali dan lebih bagus; dakwah Islam akan makin marak dan masif bahkan pesantren akan segera berdiri; anggapan tentang teroris itu diidentikkan dengan Islam adalah keliru; Kami menunggu kalian semua jamaah GIDI dalam damai kasih Islam; Kami berharap tak lama lagi kami bisa menjadi imam salat di sana, berceramah dan melantunkan azan lima waktu".

\section{SOLUSI}

Mewujudkan toleransi secara bertahap perlu diwujudkan dalam pendidikan toleran dan mewujudkan lembaga dialog lintas agama. Pertama, pendidikan toleran harus diwujudkan. Adapun cara yang dilakukan, pertama, materi pembelajaran menyertakan dan melibatkan model toleransi secara nyata dalam bentuk interaksi antarlembaga pendidikan dan antarsiswa yang beda agama dalam forum yang dibentuk dan difasilitasi oleh dinas pendidikan setempat.

Kedua, seringnya dialog antar-umat agama dalam wadah lembaga nonformal maupun formal dengan bekal kesadaran tinggi. Pada hari libur nasional keagamaan, apa pun hari raya agama yang dirayakannya, semua 
lembaga pendidikan formal harus libur. Sebagai modal awal untuk mewujudkan kehidupan toleran. Tentunya diawali dengan interaksi intensif, positif, dan akrab antar-umat beragama. Hal ini merupakan kebutuhan sesama umat manusia meski berbeda agama diwujudkan dalam kehidupan nyata sehingga bila terdapat bintik-bintik konflik segera tertangani karena tercipta saling menyadari. Adanya kesepakatan meskipun tak tertulis bahwa hal-hal yang didialogkan tidak berada pada wilayah teologi atau ajaran agama tetapi mendialogkan jalan keluar untuk memenuhi kebutuhan hidup yang berbasis kemanusiaan. Kedua hal tersebut bila terwujud maka upaya meminimalisasi pemicu terjadinya konflik antar-umat beragama yang bersumber dari perilaku umat beragama akan terealisasi.

Konflik yang dialami manusia karena adanya perbedaan menjadi tradisi yang harus diakhiri dengan modal dialog. Pemuka semua agama di Indonesia perlu mengembangkan sikap rendah hati, menghormati agama lain atau sekte lain yang seagama, dan tidak memaksakan keyakinannya pada pihak lain. Hal itu diperlukan untuk membangun kebebasan dan kerukunan intern dan antarumat beragama sebagaimana amanat Pancasila dan UUD 1945. Tokoh agama yang arogan berarti tidak memahami ajaran agamanya secara benar. Orang yang tahu tentang Tuhan pasti rendah hati karena menyadari manusia itu terbatas. Menyikapi hal itu, perlunya manajemen konflik kontekstual untuk mengantisipasi konflik laten dan terbuka dengan pendekatan pertemuan dan dialog dari hati ke hati yang menyejukkan suasana batin. Nilai dasar kemanusiaan berupa keadilan, kerukunan, dan persaudaraan dijunjung tinggi. Hal itu sebagai modal dasar menumbuhkan rasa kebersamaan meski beda SARA (Suku, Agama, Ras, dan Antargolongan).

Prinsip berdialog tidak dapat dilakukan dalam konteks antar-umat beragama yang awam, kajiannya berada pada ranah prinsip akidah yang berbeda. Untuk dialog umat seagama yang berbeda aliran pun mengedepankan prinsip saling memahami perbedaan prinsip. Konsekuensinya, tidak timbul ketegangan yang bermuara pada konflik. Modal dasarnya adalah perbedaan untuk dikelola (yang dikenal manajamen konflik), yakni menyikapi lapang dada di tengah adanya perbedaan. Dialog menurut Daya dilakukan sebagai cara untuk membudayakan kehidupan rukun dan harmonis secara vertikal (dengan Tuhan) membuahkan kehidupan yang suci dan indah. Adapun horizontal (sesama manusia) untuk menciptakan ketertiban, keserasian, kedamaian, kerja sama, dsb. ${ }^{28}$ 
Ketiga, memahami syiar agama. Ajaran agama samawi secara eksplisit maupun implisit mengajarkan pada umatnya untuk menyiarkan, mendakwahkan atau memisionariskan agama kepada sesamanya. Dengan ajaran tersebut, pemeluk agama pada umumnya memenuhi ajaran menyiarkan agamanya kepada sesamanya. Jika tidak mewaspadai karena dibalut fanatisme sempit, peluang terjadinya konflik menjadi realitas yang tak terelakkan. Sebagian komunitas menyadari dampak negatif pemahaman tersebut sehingga melakukan langkah riil dengan cara menjembatani jika terjadi kesalahan dalam menyiarkan ajaran agama masing-masing agar tercipta saling memahami antarpemeluk agama.

Ketiga hal tersebut berpijak pada (1) Surat Keputusan Bersama (SKB) Menteri Agama dan Menteri Dalam Negeri Nomor 1 Tahun 1979 Pasal 1 (1) pelaksanaan penyiaran agama tidak dibenarkan untuk ditujukan terhadap orang yang telah memeluk/menganut agama lain dengan cara membujuk dengan atau tanpa pemberian barang, uang, pakaian, makanan, atau minuman, pengobatan, obata-obatan dan bentuk pemberian apa pun lainnya agar orang atau kelompok orang yang telah memeluk/ menganut agama yang lain berpindah dan memeluk/menganut agama yang disiarkan. Menyebarkan pamflet, majalah, buletin, buku-buku dan bentuk barang penerbitan, cetakan lainnya kepada orang atau kelompok orang yang telah memeluk/menganut agama yang lain. SKB Menag dan Mendagri Nomor 1 Tahun 1979 Pasal 4 melakukan kunjungan dari rumah ke rumah umat yang telah memeluk/menganut agama yang lain. Hal tersebut tidak menjadi konflik bagi kalangan yang terdidik dan tidak fanatis atau pemberian dalam forum ilmiah (diskusi, sarasehan, bedah buku, dsb.). (2) Peraturan Bersama Menteri (PBM) Nomor 9 dan 8 Tahun 2006 tentang Pedoman Pelaksanaan Tugas Kepala/Wakil Kepala Daearah dalam pemeliharaan kerukunan umat beragama dan pendirian rumah ibadah. Pada Bab IV Pasal 23 syarat mendirikan tempat ibadah harus disetujui minimal 90 umat beragama dan minimal 60 umat agama lain di lingkungan rencana pendirian tempat ibadah dan rekomendasi tertulis FKUB kab/kota. Persoalan yang muncul, pemda harus memfasilitasi pendirian tempat ibadah bila tidak disetujui minimal 60 dari umat agama lain. Memfasilitasi inilah yang kurang mendapat perhatian Pemda pada umumnya

Terdapat celah yang perlu digarap agar ide mendialogkan antaragama oleh antarpemeluk agama yang difasilitasi oleh tokoh agama. Hal ini dilakukan agar tidak terjadi konflik dan saling memahami prosedur dan 
cara berinteraksi sosial antarpemeluk agama dengan cara, pertama, mendewasakan tokoh agama mulai tingkat lokal atau sekup kecil. Kedua, antartokoh agama mulai dari arus terbawah didewasakan dengan cara difasilitasi dalam forum silaturahim berkala. Ketiga, mengoptimalkan peran Forum Komunikasi Umat Beragama (FKUB). Keberadaan FKUB berdasarkan Peraturan Bersama Menteri Agama dan Menteri Dalam Negeri (PBM) Nomor 9 dan 8 Tahun 2006 tentang Pedoman Pelaksanaan Tugas Kepala Daerah/Wakil Kepala Daerah dalam Pemeliharaan Kerukunan Umat Beragama, Pemberdayaan Forum Komunikasi Umat Beragama dengan melibatkan person dalam keanggotaan orag yang toleran.

Menurut Banawiratma, dkk. dialog antar-umat beragama dapat dilakukan dalam ragam aspek secara berurutan dan berkesinambungan. Pertama, dialog kehidupan yang diawali dari komunitas kecil yang menghadapi hidup keseharian bersama, saling mengenal, mempunyai keprihatinan bersama, sehingga muncul kepedulian bersama. Kedua, membuat analisis sosial dan merumuskan pilihan etis dan konteks yang ada. Ketiga, menggali tradisi iman masing-masing untuk memecahkan persoalan kehidupan. Keempat, dialog dengan membagi pengalaman iman dalam komunitas lintas iman. Kelima, dialog yang terjadi dalam pergumulan teologi lintas iman dan agama dalam memahami aspek ilmiah. Keenam, dialog aksi, yakni mengkaji masalah sosial dalam melibatkan masyarakat. Ketujuh, dialog intraagama agar tercipta otokritik terhadap penghayatan iman seseorang untuk peneguhan. ${ }^{29}$ Tahapan dialog ini menurut penulis, hal yang harus disiapkan sebagai dasar aksi masing-masing pihak yang berdialog (1) sudah menyadari dan memahami ajaran agamanya secara matang, (2) kedua belah pihak tidak mempunyai harapan untuk mengajak dan mengubah akidah seseorang untuk bergabung menjadi jemaat/ umatnya, (3) saling menyadari di tengah suka dan dukanya sebagai sesama umat manusia sehingga muncul empati dan simpati untuk saling memulyakan.

Rasa sepenanggungan, kesetiakawanan, dan kebersamaan menjadi 'barang mahal' di tengah pesan negatif globalisasi dan pemahaman sempit pemeluk agama dalam masyarakat majemuk. Jika hal ini tertradisi tanpa adanya reserve dikhawatirkan menumpulkan perasaan hati antarsesama dan munculnya kesenjangan sosial. Solusi bijak yang perlu dikedepankan adalah pemahaman dari diri untuk diri bahwa kehidupan manusia sebagai makhluk sosial tak akan mampu 'sendiri', tapi membutuhkan empati dan 
simpati pihak lain. Tetapi jika memahami diri lain (the others) tidak hanya dengan kaca mata diri juga menggunakan kaca pandang diri lain, sehingga tercipta keseimbangan dan terjauhkan diri dari sakwasangka (buruk sangka, negatif thinking, suudon).

Kemajemukan dipahami sebagai kumpulan berbagai elemen sosial yang menyatu dalam lingkungan yang sama meski berpeluang terjadi perbedaan. Perbedaan tak untuk dijadikan modal konflik, tapi untuk dipahami bahwa ketidaksamaan dalam berbagai lini adalah produk Ilahi untuk disadari dan disyukuri. Perbedaan sebagai cara memahami diri atas pihak lain sebagai modal sosial untuk membangun kehidupan bermasyarakat. Saling menghormati terhadap pihak liyan (the others) berbekal hati nurani. Jika ruh hati nurani tersebut tumpul, maka rusaklah nurani yang paling murni yang dimiliki manusia. Dengan teori tersebut pada dasarnya, Pertama, harmoni interaksi sosial; terciptanya keselarasan sosial, manakala dalam bersesama, manusia mengedepankan sifat seimbang (at-tawazun) kaitannya dengan menerima informasi dari berbagai sumber, masudnya tak latah menghakimi salah, toleran (at-tasamuh) maksudnya memahami dan menghormati di tengah perbedaan, khususnya beda agama atau aliran, dan adil (al-adalah) yakni bersikap tegas jika menjadi penguasa dalam menegakkan hukum. Kedua, empati sosial; kesadaran identitas sosial dalam meningkatkan kapasitas empati sebenarnya dapat dilakukan dengan lebih menambah kesadaran diri (self-aware autonomy) dan mengurangi tendensi mengklaim apa yang benar dan apa yang salah. Kesadaran diri/ mawas diri bahwa setiap orang memiliki keunikan, kelebihan, dan kekurangan yang dapat saling melengkapi. Ketiga, perlunya memformat dialog intern dan antaragama; konflik berlatar belakang agama merupakan salah satu masalah serius di Indonesia. Salah satu penyebab ketidaknyamanan sosial dipicu oleh persepsi dan pemahaman umat terhadap ajaran agama yang didukung oleh sempitnya pemahaman dan merasa paling benar dan yang lain salah.

Berpikir sempit tersebut imbas negatif dalam mewarisi pola pikir masa lalu yang dibentuk oleh pola stratifikasi sosial sejak era kolonial terdiri (1) orang Eropa di Nusantara, (2) orang Timur Asing (Vreemde Oosterlingen) yakni Tionghoa, Arab, India, Pakistan, dll, (3) pribumi/bumiputra (inlander) masih melekat dalam benak warga kita hingga kini. Hal itu dipicu kecemburuan sosial yang tanpa memahami faktor pembeda, terutama aspek ekonomi. Di sisi lain, kehidupan sosial etnis minoritas tak selalu membaur 
dengan lingkungannya yang mayoritas memicu segregasi sosial. Bila hal ini terus terjadi, perjuangan leluhur (etnis) akan tertumpuk oleh aura negatif generasi kini. Hal itu perlu disikapi dengan format dialog yang sangat ditentukan dengan kondisi riil, sehingga tiap persoalan dan di tiap daerah terdapat perbedaan format dialog.

\section{KESIMPULAN}

Ketegasan pemerintah dalam menindak bagi pemerintah daerah tatkala membuat perda yang bertentangan dengan amanat UUD 1945 dan perundangan lainnya harus diwujudkan. Bila tidak, mewujudkan toleransi beragama tak akan terwujud. Hal ini sebagaimana diproduknya perda di Kabupaten Tolikara Papua yang melarang umat agama mendirikan tempat ibadah selain yang tergabung dalam GIDI. Perda tersebut sebagai embrio terjadinya konflik berupa pembakaran masjid at-Muttaqin di Tolikara pada 1 Syawal $1436 \mathrm{H} / 2015 \mathrm{M}$ tatkala muslim setempat melaksanakan salat Idul Fitri 2015. Kejadian tersebut memicu riak kecil di daerah lain sehingga memerlukan kesigapan semua elemen bangsa. Penegakan hukum dan vonisnya diinformasikan secara terbuka pada publik agar menjadi pelajaran. Pemulihan pasca-konflik pun harus mendapat pengawalan dan difasilitasi sepenuhnya oleh pemerintah agar luka yang pernah terkuak segera pulih. Kenyamanan sosial harganya mahal sehingga perlu dirawat dengan mengoptimalkan pendidikan yang menanamkan nilai-nilai toleransi di bangku pendidikan dan pendidikan informal (oleh orangtua di rumah), mengoptimalkan peran forum komunikasi umat beragama (FKUB), dan mewadahi adanya komunitas lintas agama sebagai wadah interaksi sosial agar terwujud harmoni.

Harmoni pada dasarnya realitas yang tercipta kenyamanan antar dan intern-umat beragama. Terciptanya harmoni sebagai wujud terhindari dari konflik. Konflik lazimnya dipicu oleh perbedaan ajaran agama bagi pemeluk agama yang memahami ajaran agama secara parsial, tanpa memahami pesan substansial. Penelitian ini berpijak dari asumsi dasar bahwa pendekatan budaya yang didialogkan dalam kehidupan sehari-hari oleh antarpemeluk agama dengan sesama pemeluk agama agar mampu mengurai konflik atau mengantisipasi konflik. Upaya yang dilakukan dengan mengedepankan empati sosial dan memunculkan sepenanggungan dalam berbuat dan berpikir untuk mewujudkan harmoni (keselarasan) hidup antarsesama umat manusia. 
Untuk mewujudkan harmoni bila tercipta (1) kenyamanan interaksi sosial yakni terciptanya keselarasan sosial, manakala dalam bersesama, manusia mengedepankan sifat seimbang (at-tawazun) kaitannya dengan menerima informasi dari berbagai sumber, masudnya tidak latah menghakimi salah dan toleran (at-tasamuh) maksudnya memahami dan menghormati di tengah perbedaan, khususnya beda agama atau aliran, serta adil (al-adalah) yakni bersikap tegas jika menjadi penguasa dalam menegakkan hukum, (2) empati sosial yakni kesadaran identitas sosial setiap individu dalam meningkatkan kapasitas empati yang sebenarnya. Hal ini dapat dilakukan dengan lebih menambah kesadaran diri (self-aware autonomy) dan mengurangi tendensi mengklaim apa yang benar dan apa yang salah. Kesadaran diri/mawas diri bahwa setiap orang memiliki keunikan, kelebihan, dan kekurangan yang dapat saling melengkapi. ${ }^{30}$ (3) menghindari atau meminimalisasi perilaku agresif karena berperan sebagai faktor pemicu kekerasan dan sumber konflik. Keberadaan konflik dapat dijadikan grand design penyelesaian konflik (manajemen konflik) dengan tahap jangka pendek, menengah, dan panjang. Tahapan tersebut perlu memahami karakter konflik yakni faktor apa yang memicu dan penyelesaiannya dituntaskan dengan mencari akar persoalan. Perlu pula ketegasan dalam penegakan hukum.

Ketenteraman jiwa yang berimbas kenyamanan raga bagi diri dan lingkungan pemeluk agama sebagai kebutuhan manusia sepanjang kehidupan. Beragama memerlukan kenyamanan hidup, agar tercipta interaksi yang interaktif intern dan antarpemeluk agama, konsep yang diusung oleh pemeluk agama, agamawan, dan ilmuwan adalah mewujudkan toleransi beragama. Dasar terciptanya toleransi jika antarpemeluk agama menyadari dan mendasari diri bahwa keyakinan bagi individu pemeluk agama adalah wilayah pribadi, seyogyanya tidak saling 'menuding' sebagai ekspresi frontal pemeluk agama terhadap pihak lain. Diperkuat dengan dalih, bagaimana jika 'pribadi' kita dikoyak pihak lain. Jika hal tersebut tertanam pada sanubari warga dunia, tentunya konflik yang sumbunya agama, ras, dan antargolongan tidak akan terjadi, meskipun kenyamanan beragama juga ditentukan oleh peran negara, sebagaimana negara China -Biro Urusan Agama Negara- yang mengeluarkan peraturan tentang akuntansi pada organisasi keagamaan dan melaporkan keuangannya tiap tahun, sekaligus untuk memperketat kontrol terhadap kelompok berbasis kepercayaan. Hal tersebut karena pemberian 
kebebasan beragama bagi warganya, dalam praktiknya oleh Partai Komunis yang ateis membatasi kelompok keagamaan melalui proses registrasi dan birokrasi (Kompas, 20 Maret 2010).

\section{CATATAN AKHIR}

1 Kompas, 30 Juli 2015.

2 yakni kebijakan satu harga yang berlaku di seluruh Indonesia termasuk Papua dan Papua Barat. Hal ini mendorong pembukaan agen penyalur minyak dan solar (APMS) dan pembangunan stasiun pengisian bahan bakar umum (SPBU) yang menurunkan harga bensin dan solar menjadi sama dengan daerah lain di Indonesia. Tatkala presiden berkunjung di Wamena, harga bensin per liter harga normal Rp 60 ribu dan bila tidak normal menjadi Rp 100 ribu, apalagi di Puncak Jaya. Sekembalinya dari kunjungan kerja, Jokowi mengundang menteri terkait untuk menyelesaikannya. Setelah setahun, harga BBM di Papua menjadi Rp 6.450 untuk premium dan solar Rp 5.150 per liter di 9 lokasi dari 33 lokasi. Kesembilannya adalah Kecamatan Ilaga, Kabupaten Puncak, Papua; Kecamatan Elelim, Kabupaten Yalimo, Papua; Kecamatan Kenyam, Kabupaten Nduga, Papua; Kecamatan Kasonawega, Kabupaten Mamberamo Raya, Papua; Kecamatan Kobakma, Kabupaten Memberamo Tengah, Papua; Kecamatan Karubaga dan Wenam, Kabupaten Tolikara (yang ditelaah dalam naskah ini), Papua; Kecamatan Supaga, Kabupaten Intan Jaya, Papua; Kecamatan Anggi, Kabupaten Pegunungan Arfak, Papua Barat; dan Kecamatan Moswaren, Kabupaten Sorong Selatan, Papua Barat (Detikfinance.com, Senin 17 April 2017).

3 Selasa 22 Agustus 2017 Menteri BUMN Rini Soemarno melakukan program semen $40 \mathrm{~kg}$ dengan harga subsidi di tujuh kabupaten di wilayah Pegunungan Tengah, Papua yakni Jayawijaya, Tolikara, Puncak, Puncak Jaya, Nduga, Yalimo, dan Mamberamo Tengah. Tujuannya untuk mengurangi beban biaya pembangunan infrastruktur di daerah pedalaman. Lima BUMN yang terlibat yakni PT Semen Indonesia, PT Pelni, PT Pelindo IV, PT Perusahaan Perdagangan Indonesia (PPI), dan PT Pos Indonesia. Selama ini, harga semen per sak Rp 2 juta akan diturunkan menjadi Rp 500 ribu. Upaya pemerintah dengan memperbaiki sistem transportasi agar pengangkutan ke pedalaman tersebut murah. Jalur yang ditempuh, semen Tonasa dari Makassar (Sulsel) ke Timika (Kabupaten Mimika, Papua) dilanjutkan dengan pesawat ke Wamena dan didistribusikan ke Puncak Jaya serta lima kabupaten lainnya. PPI berperan sebagai distributor ke tujuh kabupaten bekerja sama dengan pesawat kargo (Kompas, Rabu 23 Agustus 2017).

4 Kelompok Pakar Penamaan Geografi Perserikatan Bangsa-Bangsa (UNCSGN) di New York 18 Agustus 2017 mengesahkan 16.056 pulau di Indonesia melalui survei toponimi. Sejak 2015 hingga Juli 2017 Indonesia melalui tim Kementerian Kelautan dan Perikanan (KKP), Kemenlu RI, dan Badan Informasi Geospasial (BIG) RI memverifikasi 2.590 pulau bernama dan 
berkoordinasi melalui survei toponimi tahap kedua. Pengesahan PBB diawali upaya BIG selaku otoritas Penamaan Rupa Bumi Nasional bersamaa KKP, Pusat Hidrografi dan Oseanografi TNI AL, Kementerian Koordinator Kemaritiman dan Kementerian Koordinator Politik, Hukum, dan Keamanan, dan pemda (terkait). Pemerintah sedang memverifikasi sekitar 850 pulau yang tertebar di Jambi, Sumsel, Jatim, Kalsel, Kalteng, NTT, Maluku, dan Papua Barat. Hal ini sebagai fakta kekayaan alam yang meruah untuk dirawat dengan mengutamakan kesejahteraan warga dengan mengoptimalkan sumber penghasilan dan mengendalikan biaya hidup yang tinggi. Tidak sebandingnya penghasilan dengan biaya hidup merupakan pangkal kemiskinan.

5 Kompas, 16 Agustus 2014.

6 Kedekatan secara teritorial antara Indonesia (Papua) dengan Papua Niugini, sehingga tatkala Era Orde Baru, warga Papua korban politik karena berbeda ideologi masih ketakutan kembali ke Indonesia karena trauma menjadi korban pelanggaran HAM. Data Konsul Indonesia untuk Vanimo, Papua Niugini terdapat 12.000 warga Papua mengungsi di Papua Niugini sejak 1984 hingga kini. Mereka berasal dari Jayapura, Biak Numfor, Merauke, dan Kepulauan Yapen yang tertebar di Vanimo, Port Moresby, Lae, dan Wewak. Pengungsi tersebut meresahkan warga Papua Niugini karena mengambil alih tanah untuk lahan pertanian. Kondisinya memprihatinkan karena anak-anak tidak sekolah, akibat hidupnya berpindah-pindah dan tak berkewarganegaraan hingga kini. Meskipun demikian, mereka belum mau kembali ke Indonesia karena terpengaruh informasi negatif tentang Indonesia (Kompas, 7 November 2014).

7 Sebagaimana Komnas HAM RI memanggil Wali Kota Kupang Nusa Tenggara Timur Jonas Salean untuk dimintai penjelasan terkait terhambatnya pembangunan Masjid Nur Musafir di Kelurahan Batuplat, Kecamatan Alak, Kota Kupang. Berdasarkan pengaduan umat Islam di Batuplat, panitia pembangunan masjid telah mendapatkan izin mendirikan bangunan (IMB) 15 Juli 2011, hibah tanah seluas 1.000 m dari Pemkot Kupang untuk pembangunan masjid baru dilakukan tujuh hari kemudian, 22 Juli 2011. Bahkan Wali Kota Kupang telah meletakkan batu pertama pembangunan. Akan tetapi, karena ada dugaan dari warga setempat (Kristen) bahwa ada penyimpangan sejak proses awal pembangunan, yakni yang menandatangani persetujuan pembangunan masjid hanya Ketua FKUB tanpa melalui musyawarah (Kompas, 31 Januari 2015). Setelah kasus tersebut dilaporkan Komnas HAM RI dan dimediatorinya maka pada Senin 31 Agustus 2015 Komnas HAM mengajak dialog dengan Pemda setempat, Kemenag, Ketua Sinode Gereja Masehi Injili Timor, FKUB, dan tokoh pemuda menemukan titik temu untuk damai. Padahal, merujuk Pasal 14 (3) Peraturan Bersama Menteri (PBM) Nomor 8 dan 9 Tahun 2006 Tanggal 21 Maret 2006 bahwa pemda berkewajiban memfasilitasi tersedianya lokasi pembangunan rumah ibadah bila dukungan masyarakat setempat minimal 60 orang belum terpenuhi. Perlunya melaksanakan UU Nomor 25 Tahun 2009 tentang Pelayanan Publik. Hal ini bila tidak disikapi dengan langkah bijak secara riil 
oleh berbagai elemen masyarakat dan pemerintah, maka konflik berkepanjangan antar dan intern-umat beragama menjadi penyakit akut. Dengan demikian, perlu upaya yang bersumber dari lingkungan keluarga dan lingkungan pendidikan dalam menanamkan nilai agama yang toleran.

8 Mudjahirin Thohir. Mengurai Kekerasan Keagamaan. Suara Merdeka, 21 Februari 2011, hlm.1.

$9 \quad$ M.Dawam Rahardjo. Fanatisme dan Toleransi dalam pengantar buku Berislam secara Toleran Teologi. 2011 Kerukunan Umat Beragama karya Irwan Masduqi. Mizan: Bandung, hlm. xxvii.

10 Moh Rosyid. Mewujudkan Pendidikan Toleransi antarumat Beragama di Kudus: Belajar dari Konflik Tolikara Papua 1 Syawal 1436 H/2015 M. Quality Jurnal Prodi Manajemen Pendidikan Islam Program Pascasarjana STAIN Kudus, 2016. hlm.378.

11 Toni Victor M. Wanggai. Rekonstruksi Sejarah Umat Islam di Tanah Papua. Balitbang Kemenag RI: Jakarta. 2009.

12 Kompas, 29 September 2010.

13 Perda Provinsi Bali Nomor 3 Tahun 2005 menandaskan bahwa bangunan gedung di Bali tingginya tidak diperbolehkan melebihi tingginya pohon kelapa (maksimal $15 \mathrm{~m}$ ). Perda tersebut bertujuan menghormati tempat yang suci dan disucikan perspektif adat di Bali. Gubernur Bali I Made Mangku Pastika mengklarifikasi munculnya Perda yang berdasarkan kepercayaan tersebut kepada pedanda (ahli tradisi Bali). Klarifikasi tersebut tak mendapatkan jawaban ideal dari pedanda. Perda dianggap mengganggu kesinambungan pembangunan fasilitas umum komersial, seperti hotel berbintang, jalan layang, dan lainnya. Akhirnya muncul inisiatif untuk meninjau kembali Perda tersebut. Ketika naskah ini ditulis, penulis belum mendapat informasi hasil peninjan kembali terhadap Perda Nomor 3 Tahun 2005. Realitas tersebut menandaskan bahwa membangun dalam bentuk bangunan yang tinggi di Bali perlu memahami budaya yang berbasis ajaran agama Hindu di Bali, kaitannya dengan menghormati tempat suci. Bila pemahaman terhadap kearifan lokal lemah, dikhawatirkan terjadi konflik, mengubah ajaran dasar agama

14 Sejak manusia jumlahnya terbatas telah terjadi konflik hingga pembunuhan, sebagaimana dilakukan oleh putra Nabi Adam AS, Qabil (kakak) dengan Habil (adik) ketika Adam pergi ke Makkah (al-Maidah:27-30). Sejak awal, Adam akan menghuni bumi, Allah mewanti-wanti bahwa sebagian anak-cucu Adam bermusuhan (Al-A'raf:24-25). Para sejarawan berpendapat bahwa Hawa (dari surga turun/hadir di dunia di Jeddah, ada yang menyebut di bukit Marwah) dan Adam (turun di India, ada yang menyebut di Soffa). Hawa melahirkan anak sebanyak 20 kali, setiap melahirkan selalu kembar dampit, putra dan putri (jumlah anak 40). Adam menikahkan anaknya model silang (anak lelaki pertama dengan perempuan kedua). Anak pertama lelaki Qabil dengan anak perempuan Zar'a (ada yang menyebut Iklima). Disusul kelahiran berikutnya Habil dengan Dhar (ada yang menyebut Labuda). Kakak beradik 
yang hidup di era ketika dunia masih terbatas jumlah penghuninya pun terjadi perebutan calon isteri hingga terjadi pembunuhan. Peristiwa serupa terjadi berkelanjutan yang beragam faktor pemicunya. Untuk mengakhiri konflik, penduduk dunia sadar dengan membentuk Perserikatan Bangsa-Bangsa (PBB). Akan tetapi, lembaga dunia ini masih tak bernyali bila menghadapi gertakan Amerika yang berperan sebagai penyandang dana terbesar. Gertakan Amerika pada dasarnya hanya untuk melindungi kepentingannya bila PBB berperan sebagai pendamai dunia. Solusi lain selalu kandas karena aksi untuk menjadi pelindung dunia adalah kekuatan materi. Dengan demikian, bagi Negara yang tidak memiliki dana besar, maka menjadi pahlawan perlu upaya ekstragigih.

15 Bagong Suyanto. Peringatan Dini Sosial. Kompas, 17 Februari 2011, hlm.6.

16 Data Komnas HAM 2011, terjadi 819 sengketa lahan, 451 sengketa industrial perburuhan, 300 kasus kepegawaian, 193 penggusuran paksa, 120 kasus lingkungan, 84 kasus kebebasan beragama, 79 kasus masyarakat adat, 75 kasus buruh migran, dan 50 kasus kesehatan. Pihak yang dikeluhkan kepolisian (1.503), perusahaan (1.119), pemda (779), pengadilan (544), UMN (273), kejaksaan (264), TNI (223). Masalah utamanya hak memperoleh keadilan (2.466), kesejahteraan (2.317), rasa aman (948), hak hidup (191), perempuan (126), anak (74), dan hak turut serta berpemerintahan (61). Kasusnya tersebar di Jakarta (1.211), Jatim (758), Sumut (640), Jabar (586), Sumbar (364), Sumsel (204), Riau (282), dan Lampung (72). Hal itu terjadi di tengah berlakunya UU Nomor 40 Tahun 2008 tentang Penghapusan Diskriminasi Ras dan Etnis Pasal 1 (1) diskriminasi ras dan etnis adalah segala bentuk pembedaan, pengecualian, pembatasan, atau pemilihan berdasarkan pada ras dan etnis, yang mengakibatkan pencabutan atau pengurangan pengakuan, perolehan, atau pelaksanaan hak asasi manusia dan kebebasan dasar dalam suatu kesetaraan di bidang sipil, politik, ekonomi, sosial, dan budaya.

17 Alwi Shihab. Islam Inklusif. Mizan: Bandung. 1999.

18 Penganut ajaran sesat di Afrika Timur meyakini bahwa setiap organ tubuh seorang albino berkekuatan magis untuk jimat, membawa kekayaan, dan nasib baik. Sepotong tubuh albino dihargai 75.000 dollar AS atau Rp 713 juta. Dampaknya, 44 orang albino tewas di Tanzania dan 14 lainnya disembelih di Burundi, sehingga 10 ribu kaum Albino bersembunyi (Kompas, 30 November 2009). Begitu pula anarkhisnya bom yang menewaskan 185 orang saat perayaan Misa Natal 2011 di Gereja Santa Theresa, Gereja Jos, Gereja di Damaturu di Madalla, Abuja, Nigeria. Kelompok militan garis keras, Boko Haram -anggota sayap Al Qaeda di Afrika Barat yang menginginkan negara agama dengan sistem pemerintahan syariah Islam, melawan negara sekulermengklaim bertanggung jawab. Boko memanfaatkan tentara bayaran dari Chad yang kemudian ditangkap (Kompas, 27 Januari 2012).

19 Sebagaimana Al-Qiyadah al-Islamiyah (QI) mengakui Ahmad Mushaddeq sebagai nabi baru (pengganti atau penerus Nabi Muhammad SAW) memiliki formulasi syahadat baru dan menghilangkan kewajiban ritual Islam. Ajaran 
ini difatwa sesat, Ahmad Mushaddeq dihukum 4 tahun penjara atas tuduhan penodaan terhadap Islam. Kemunculan QI akhir tahun 2007 direaksi keras oleh muslim karena meresahkan masyarakat karenan ajarannya menyesatkan muslim. Ajarannya, masih ada nabi dan rasul setelah Nabi SAW yakni AlMasih Al-Maw'ud atau imam agung yang ditunggu-tunggu yakni diri Ahmad Mushaddeq. Syahadatnya Asyhadualla Ilaaha illallah Waasyhaduanna Al-Masih Al-Maw'ud Rasulullah. Ibadah dalam Islam belum wajib dilakukan yakni salat, puasa, zakat dan haji karena ibadah itu dilakukan bila Islam tegak di bumi, sekarang ini dianggap belum tegak), bertentangan dengan perikemanusiaan.

20 Islam Jamaah dimotori K.Nurhasan al-Ubaedah dibantu H. Nurhasyim tahun 1950-an di Kediri Jawa Timur. Terdapat 3 perbedaan mendasar dengan Islam lainnya yakni kepemimpinan (amir), makna Islam, dan baiat. Kritik Islam Jamaah terhadap pemeluk Islam berupa (1) pendefinisian Islam yang berbelitbelit, memahami Islam tak harus mengkaji fiqih, tauhid, akhlak dsb. cukup diajarkan Quran Hadis seperlunya karena mereka akan diberi pemahaman oleh Allah, (2) Islam belum melahirkan amir yakni orang yang tinggi ilmunya, saleh, dan dianggap mampu menunjukkan jalan paling benar bagi umatnya sesuai kehendak Allah. Fungsi amir berupa imam salat, pengajar Quran-Hadis, sumber fatwa, pengatur kehidupan keagamaan, dan pemimpin spiritual bagi diri dan jamaahnya, dan (3) kelemahan ketiga berkaitan dengan kelemahan kedua yakni tak adanya baiat kaum muslimin terhadap seorang yang layak menjadi imam dalam salat maupun di luar salat) dan kebijakan bidang agama.

21 Masdar Hilmy. "Quo Vadis” Kebebasan Beragama. Kompas, 1 Maret 2011. Hlm.7.

22 Majalah Tempo, edisi 27 Juli s.d 2 Agustus 2015:32-41.

23 Kompas, 20 Juli 2015.

24 Kompas, 21 Juli 2015.

25 Suara Merdeka, 1 Agustus 2015.

26 Azyumardi Azra. Pasca Tolikara. Kompas, 28 Juli 2015, hlm.15.

27 Denny, J.A. Menjadi Indonesia Tanpa Diskriminasi Data, Teori, dan Solusi. Inspirasi: Jakarta. 2014, hlm.131.

28 Burhanuddin Daya. Agama Dialogis Merenda Dialektika Idealitas dan Realita Hubungan antar-Agama. Mataram-Minang Lintas Budaya: Yogyakarta. 2004, hlm.71.

29 J.B. Banawiratma, dkk. Dialog antarumat Beragama Gagasan dan Praktik di Indonesia. Mizan: Bandung. 2010, hlm. 9-12.

30 Maya Dania. Empati dan Identitas Sosial. Kompas, 22 Desember 2011, hlm.7.

\section{DAFTAR PUSTAKA}

Azra, Azyumardi. 2015. Pasca Tolikara. Kompas, 28 Juli 2015.

Banawiratma, J.B. dkk. 2010. Dialog antarumat Beragama Gagasan dan Praktik di Indonesia. Mizan: Bandung.

Daya, Burhanuddin. 2004. Agama Dialogis Merenda Dialektika Idealitas dan Realita Hubungan antar-Agama. Mataram-Minang Lintas Budaya: Yogyakarta.

Dania, Maya. 2011. Empati dan Identitas Sosial. Kompas, 22 Desember 2011. 
Hilmy, Masdar. 2011. "Quo Vadis Kebebasan Beragama”. Kompas, 1 Maret 2011. J.A, Denny. 2014. Menjadi Indonesia Tanpa Diskriminasi Data, Teori, dan Solusi. Inspirasi: Jakarta.

Majalah Tempo, 2015. edisi 27 Juli - 2 Agustus 2015.

Rahardjo, M.Dawam. 2011. "Fanatisme dan Toleransi" dalam pengantar buku Berislam secara Toleran: Teologi Kerukunan Umat Beragama karya Irwan Masduqi. Mizan: Bandung.

Rosyid, Moh. 2016. "Mewujudkan Pendidikan Toleransi antar-umat Beragama di Kudus: Belajar dari Konflik Tolikara Papua 1 Syawal 1436 H/2015 M". Jurnal Quality. vol.3 no.2, hlm 368-409

Shihab, Alwi. 1999. Islam Inklusif. Mizan: Bandung.

Suyanto, Bagong. 2011. Peringatan Dini Sosial. Kompas, 17 Februari 2011.

Thohir, Mudjahirin. 2011. Mengurai Kekerasan Keagamaan. Suara Merdeka, 21 Februari 2011.

Wanggai, Toni Victor. 2009. M. Rekonstruksi Sejarah Umat Islam di Tanah Papua. Balitbang Kemenag RI: Jakarta. 